\title{
Size-resolved aerosol composition and its link to hygroscopicity at a forested site in Colorado
}

\author{
E. J. T. Levin ${ }^{1}$, A. J. Prenni ${ }^{1}$, B. B. Palm ${ }^{2}$, D. A. Day $^{2}$, P. Campuzano-Jost ${ }^{2}$, P. M. Winkler ${ }^{3,4}$, S. M. Kreidenweis ${ }^{1}$, P. \\ J. DeMott ${ }^{1}$, J. L. Jimenez ${ }^{2}$, and J. N. Smith ${ }^{3,5}$ \\ ${ }^{1}$ Department of Atmospheric Science, Colorado State University, Fort Collins, CO, USA \\ ${ }^{2}$ Department of Chemistry and Biochemistry and Cooperative Institute for Research in the Environmental Sciences (CIRES), \\ University of Colorado, Boulder, CO, USA \\ ${ }^{3}$ National Center for Atmospheric Research, Boulder, CO, USA \\ ${ }^{4}$ Department of Physics, University of Vienna, Vienna, Austria \\ ${ }^{5}$ Department of Applied Physics, University of Eastern Finland, Kuopio, Finland
}

Correspondence to: E. J. T. Levin (elevin@atmos.colostate.edu)

Received: 9 August 2013 - Published in Atmos. Chem. Phys. Discuss.: 11 September 2013

Revised: 17 January 2014 - Accepted: 30 January 2014 - Published: 14 March 2014

\begin{abstract}
Aerosol hygroscopicity describes the ability of a particle to take up water and form a cloud droplet. Modeling studies have shown sensitivity of precipitation-producing cloud systems to the availability of aerosol particles capable of serving as cloud condensation nuclei (CCN), and hygroscopicity is a key parameter controlling the number of available CCN. Continental aerosol is typically assumed to have a representative hygroscopicity parameter, $\kappa$, of 0.3 ; however, in remote locations this value can be lower due to relatively large mass fractions of organic components. To further our understanding of aerosol properties in remote areas, we measured size-resolved aerosol chemical composition and hygroscopicity in a forested, mountainous site in Colorado during the six-week BEACHON-RoMBAS (Bio-hydro-atmosphere interactions of Energy, Aerosols, Carbon, $\mathrm{H}_{2} \mathrm{O}$, Organics and Nitrogen-Rocky Mountain Biogenic Aerosol Study) campaign. This campaign followed a year-long measurement period at this site, and results from the intensive campaign shed light on the previously reported seasonal cycle in aerosol hygroscopicity. New particle formation events were observed routinely at this site and nucleation mode composition measurements indicated that the newly formed particles were predominantly organic. These events likely contribute to the dominance of organic species at smaller sizes, where aerosol organic mass fractions were between 70 and $90 \%$. Corresponding aerosol hygroscopicity was observed to be in the range $\kappa=0.15-0.22$, with hygroscopicity increasing with particle size. Aerosol chemical composition measured by an
\end{abstract}

aerosol mass spectrometer and calculated from hygroscopicity measurements agreed very well during the intensive study, with an assumed value of $\kappa_{\text {org }}=0.13$ resulting in the best agreement.

\section{Introduction}

Whether or not a particle will act as a cloud condensation nucleus $(\mathrm{CCN})$ at a given supersaturation depends on the particle's size and hygroscopicity, the latter referring to how readily the particle takes up water and grows to droplet size. For particles in the accumulation mode, where the majority of atmospheric particle number concentrations are typically found, aerosol hygroscopicity can have large impacts on the number of available CCN (Petters and Kreidenweis, 2007), which in turn can impact cloud droplet number and size. Higher droplet number concentrations are expected to cause changes in both cloud structure and lifetime, leading to enhancements in cloud reflectivity (Twomey, 1974), suppression of drizzle (Albrecht, 1989), changes in intensity and distribution of precipitation (Rosenfeld et al., 2008; Khain et al., 2005; Khain and Lynn, 2009; Storer et al., 2010; van den Heever et al., 2006; van den Heever and Cotton, 2007; van den Heever et al., 2011) and even changes in updraft and storm intensity (Lerach and Cotton, 2012). It is thus essential to accurately represent the number and characteristics of $\mathrm{CCN}$ in order to model these important processes. 
Hygroscopicity can be described by the hygroscopicity parameter, $\kappa$ (Petters and Kreidenweis, 2007). Typical atmospheric aerosol components can be divided into three broad categories based on hygroscopicity. Inorganic salts, such as ammonium sulfate, ammonium nitrate, and sodium chloride, are highly hygroscopic, with $\kappa$ values ranging from $\sim 0.6$ to 1.2 (Petters and Kreidenweis, 2007). Laboratory and field studies of secondary organic aerosol (SOA) species have found $\kappa$ values around $\sim 0.1$ (Prenni et al., 2007; Engelhart et al., 2008; Engelhart et al., 2011; Wex et al., 2009; Pierce et al., 2012) although individual species, when separated by polarity, show a larger range (Suda et al., 2012). Studies have shown that $\kappa$ of more oxidized secondary organic species can be as high as 0.22 (Chang et al., 2010), although Frosch et al. (2011) found no relationship between $\kappa$ and $\mathrm{O} / \mathrm{C}$ ratio for $\alpha$-pinene SOA aged in a smog chamber. Black carbon and dust are typically measured or assumed to have $\kappa$ values of $\sim 0-0.05$ (Koehler et al., 2009; Yamashita et al., 2011). As a representative average value for the fine mode aerosol that dominates $\mathrm{CCN}$ number concentrations, continental aerosol particles are often assumed to be adequately represented by a hygroscopicity parameter of $\sim 0.3$ (Andreae and Rosenfeld, 2008; Pringle et al., 2010; Pöschl et al., 2009). However, in remote locations, far from sources of anthropogenic sulfate and nitrate, organic species may represent the dominant fraction of the aerosol, leading to lower $\kappa$ values (Gunthe et al., 2009; Juranyi et al., 2011). Biogenic secondary organic aerosol (BSOA) is of particular interest in remote regions where oxidized volatile organic compounds, emitted from biogenic sources, play a key role in aerosol formation. These oxidized biogenic compounds can condense onto existing particles or contribute to new particle formation and growth (Kulmala et al., 2004a, b; Dusek et al., 2010), and have been shown to be a major source of organic aerosol mass (Kanakidou et al., 2005; Robinson et al., 2011).

Given the global significance of organic aerosol, particularly of biogenic origin, many laboratory studies have examined the hygroscopicity of various model BSOA species (Prenni et al., 2007; Petters et al., 2009b; King et al., 2010; Asa-Awuku et al., 2010; Massoli et al., 2010; Engelhart et al., 2011) while field studies have measured aerosol hygroscopicity in areas dominated by BSOA (Cerully et al., 2011; Gunthe et al., 2009; Paramonov et al., 2013; Levin et al., 2012; Sihto et al., 2011; Pierce et al., 2012). These studies have consistently found average $\kappa$ values below 0.3 , as well as variability in aerosol hygroscopicity with size, the latter feature likely due to the differing sources and gas-to-particle conversion processes of the organic and inorganic aerosol components. For example, Levin et al. (2012) measured aerosol hygroscopicity $\left(14 \mathrm{~nm}<D_{p}<350 \mathrm{~nm}\right)$ from March 2010 to May 2011 at a forested, mountainous site in Colorado as part of the ongoing Bio-hydro-atmosphere interactions of Energy, Aerosols, Carbon, $\mathrm{H}_{2} \mathrm{O}$, Organics and Nitrogen (BEA$\mathrm{CHON}$ ) project. Although the site is representative of a semiarid, mountain ecosystem, the average $\kappa$ value determined for the measured aerosol was $0.16 \pm 0.08$, similar to values measured in highly biologically active areas such as Amazonian (Gunthe et al., 2009; Pöschl et al., 2010) and boreal forests (Sihto et al., 2011). Levin et al. (2012) hypothesized that the low hygroscopicity measured during the BEA$\mathrm{CHON}$ annual cycle period was due to a large mass fraction of secondary organic species, likely of biogenic origin, in the aerosol. However, chemical composition measurements were not available during the year-long BEACHON study. In this work, we report on size-resolved CCN concentrations measured during the subsequent Rocky Mountain Biogenic Aerosol Study (BEACHON-RoMBAS), and we compare our results to concurrent measurements of size-resolved aerosol chemical composition.

\section{Methods}

\subsection{Measurement site and instrumentation}

Measurements were made during two phases of the BEACHON project: from March, 2010 to May, 2011 to study a full seasonal cycle, as previously reported (Levin et al., 2012), and during the BEACHON-RoMBAS intensive study which took place during July and August, 2011. The measurement site for both periods was located in Manitou Experimental Forest (lat. $39.10^{\circ} \mathrm{N}$, long. $105.10^{\circ} \mathrm{W}$, elevation $2370 \mathrm{~m}$ ). Kim et al. (2010), Levin et al. (2012) and Ortega et al. (2014) describe the site as well as typical transport conditions for air masses arriving at the site.

During both the year-long and the BEACHON-RoMBAS campaigns, we made measurements of size-resolved CCN concentrations at five different supersaturation $(s=\mathrm{RH}-$ $100 \%$ ) conditions and used these data to calculate aerosol hygroscopicity following Petters et al. (2009a). The specific details of the instrument setup and data collection and processing were reported in Levin et al. (2012). Briefly, we used a differential mobility analyzer (DMA; TSI 3081), operating at a 10:1.5 sheath to sample flow ratio, to select particles in 20 different size bins between $\sim 14$ and $350 \mathrm{~nm}$ in diameter. The quasi-monodisperse sample was then split and sent to a condensation particle counter (CPC; TSI 3010), 1 LPM, and a cloud condensation nucleus counter (CCNC; Droplet Measurement Technologies), 0.5 LPM. This technique provides number size distributions of total aerosol and CCN concentrations, at a specified $s$, with a $\sim 15 \mathrm{~min}$ temporal resolution. We stepped $s$ inside the CCNC through five different set points between 0.15 and $0.95 \%$. Supersaturation at each CCNC instrument setting was determined via ammonium sulfate calibrations using the thermodynamic properties of ammonium sulfate aqueous solutions as prescribed by the Aerosol Inorganics Model (Clegg et al., 1998). Calibrations at each $s$ setting were performed about once a day. Activated fractions were calculated from the size-resolved total aerosol and CCN data. The critical activation diameter $\left(d_{\mathrm{c}}\right)$, 
the diameter at which the aerosol was able to take up water and grow to cloud droplet size at a given supersaturation, was defined as the diameter where the activated fraction $=0.5$. Finally, we used the CCNC $s$ setting and the $d_{\mathrm{c}}$ to determine the best-fit aerosol hygroscopicity parameter, $\kappa$.

During BEACHON-RoMBAS, submicron aerosol composition was measured with a high-resolution time-of-flight aerosol mass spectrometer (AMS, Aerodyne Research Inc.) described by (Canagaratna et al., 2007; DeCarlo et al., 2006; Drewnick et al., 2005). The AMS measures nonrefractory material, which includes most organic species and inorganic salts other than $\mathrm{NaCl}$, but not crustal material or black carbon. While the instrument nominally measures $\mathrm{PM}_{1}$ it is most sensitive to particles with diameters between 35 and $600 \mathrm{~nm}$ (Zhang et al., 2004). The AMS was calibrated with size-selected ammonium nitrate every four days during the study. Limits of detection (LOD) for each of the AMS size bins were calculated as three times the standard error of the mean during filter measurement periods. For both organic and sulfate components, local LODs, for daily averaged data, increased roughly linearly with size across the measurement range from $0.17-0.43 \mu \mathrm{g} \mathrm{m}^{-3}$ for organics and $0.015-0.06 \mu \mathrm{g}$ $\mathrm{m}^{-3}$ for sulfate.

Nanoparticle composition was also measured with a thermal desorption chemical ionization mass spectrometer (TDCIMS) (Smith et al., 2004; Voisin et al., 2003). The TDCIMS first charges the aerosol and then uses a Nano DMA (TSI 3085) to size-select particles. The size-selected particles are then collected onto a charged wire via electrostatic precipitation. Once a suitable mass of aerosol has been collected, the wire is inserted into the chemical ionization mass spectrometer and gradually heated from room temperature to $\sim 600{ }^{\circ} \mathrm{C}$, thus desorbing the sample. For the current study, the volatilized sample was then chemically ionized and detected with a high resolution time-of-flight mass spectrometer. Due to the low mass concentrations at smaller sizes, during BEACHON-RoMBAS size selected TDCIMS measurements were only made at $30 \mathrm{~nm}$. The data presented here are averaged over two measurement periods: $3-8$ August and 15-18 August 2013.

\subsection{Aerosol composition and hygroscopicity}

The $\kappa$ value of a mixed-composition particle depends on its chemical constituents and can be calculated from volumeweighted aerosol composition (Petters and Kreidenweis, 2007):

$\kappa=\sum_{i} \varepsilon_{i} \kappa_{i}$,

where $\kappa_{i}$ and $\varepsilon_{i}$ are the hygroscopicity parameter and volume fraction of the individual components. For the Rocky Mountain region during the summer months, SOA and inorganic salts have been shown to be the main components of $\mathrm{PM}_{2.5}$ (Levin et al., 2009). While black carbon can be a signifi- cant contributor to aerosol mass during the wildfire season in the western US (Park et al., 2007), during BEACHONRoMBAS, black carbon measured with a single particle soot photometer (SP2; Droplet Measurement Technologies) accounted for only $2 \%$ of the aerosol mass averaged across all diameters below $350 \mathrm{~nm}$ (Ortega et al., 2014), similar to values reported by Levin et al. (2009) during a nonsmoke impacted time period in Rocky Mountain National Park. Dust particles may also be present in the aerosol, particularly during spring. However, dust particles typically have diameters larger than the $350 \mathrm{~nm}$ upper limit used here (Malm et al., 2009). Thus, for this study we assume that the aerosol below $350 \mathrm{~nm}$ diameter was composed mainly of SOA and hygroscopic inorganic salts, predominantly ammonium sulfate. Gunthe et al. (2009) employed similar assumptions for field measurements made in the Amazon Basin during the rainy season and found good agreement between $\kappa$ determined from size-resolved CCN measurements and calculated from AMS chemical composition measurements. In this work we follow a similar approach to Gunthe et al. (2009) to compare two-component $\kappa$ values calculated from chemical composition to $\kappa$ determined from measured $\mathrm{CCN}$ activity. We also expand this analysis to show that a representative twocomponent aerosol composition can be derived from $\kappa$, and use the year-long BEACHON $\kappa$ measurements to deduce seasonal changes in aerosol composition.

\section{Results and discussion}

\subsection{Aerosol hygroscopicity}

Figure 1 shows daily average $\kappa$ values (colored circles) and standard deviations during BEACHON-RoMBAS at the five different CCNC $s$ settings. Study averaged values ( \pm 1 standard deviation) are also reported in Fig. 1. Overall, aerosol hygroscopicity was low during this study, more similar to values reported for SOA than ammonium sulfate, and, on average, below the typically assumed value of $\kappa_{\text {continental }}=0.3$. Only at the lowest $s$ value did $\kappa$ values reach 0.3 during a few time periods. There was also little variation in $\kappa$ during the study period, especially at higher $s$ conditions. The values determined during the BEACHON-RoMBAS summer intensive study were slightly higher than those measured during the summer months of the year-long BEACHON study ( \pm 1 standard deviation of July/August means shown by gray shading in Fig. 1). However, averaged over the BEACHONRoMBAS study, $\kappa$ values at every supersaturation setting fell within 1 standard deviation of the values from the previous year.

The right axis of Fig. 1 shows activation diameters corresponding to the left axis $\kappa$ values for each $s$ setting. At lower $s$, particles of similar hygroscopicity must be larger to activate as CCN. Thus, by operating at five different $s$ settings, we are probing the hygroscopicity of particles at 


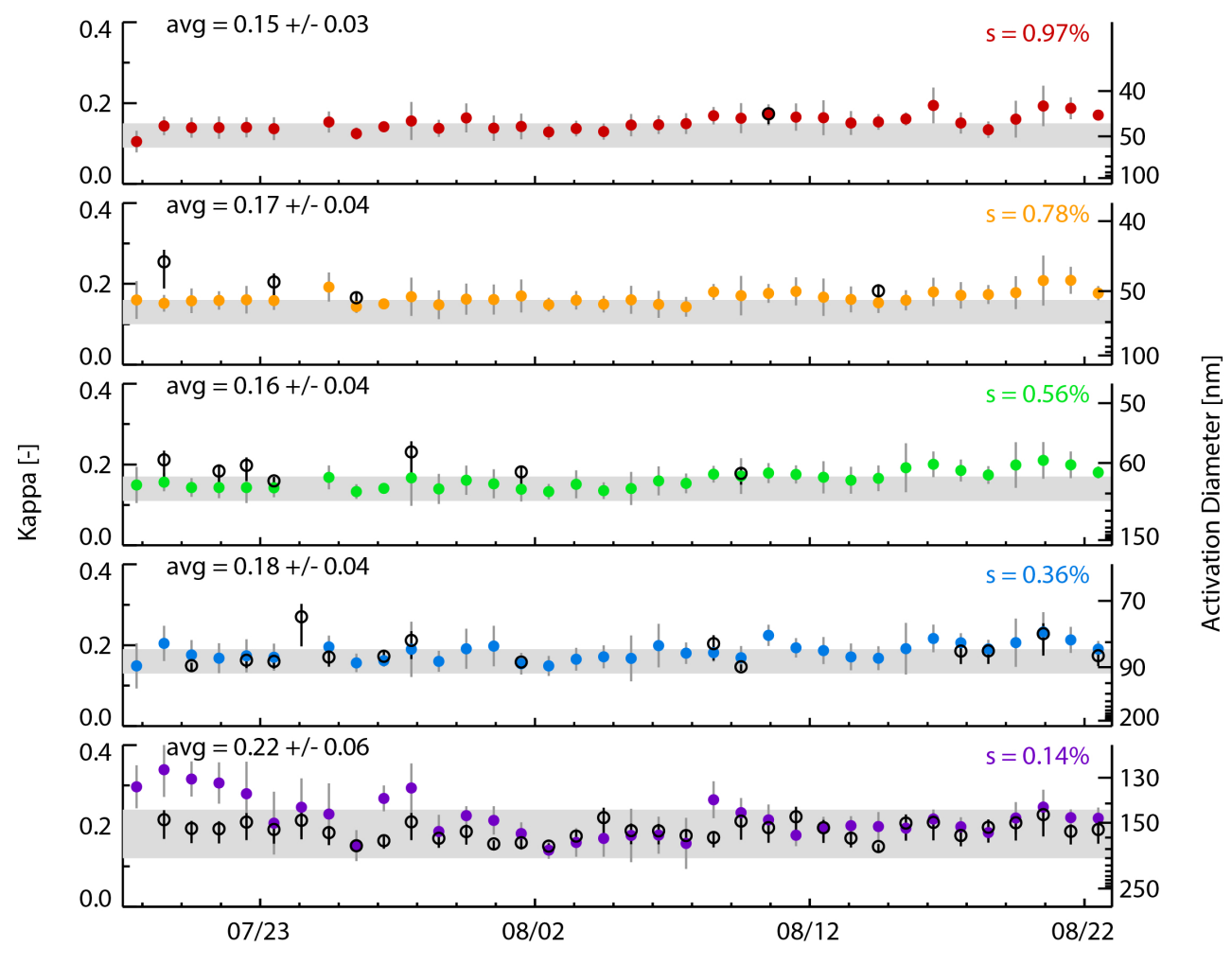

Fig. 1. Daily averaged $\kappa$ values at each supersaturation setting during BEACHON-RoMBAS (colored circles) as well as calculated $\kappa$ from AMS measurements (black circles). Gray bars show \pm one standard deviation for measured $\kappa$ values from July to August, 2011, collected during the year-long BEACHON study. Right axis indicates activation diameter corresponding to the left axis $\kappa$ values at the indicated supersaturation.

different diameters. While $\kappa$ was low at all $s$ settings, there was a small increase in $\kappa$ with decreasing $s$, corresponding to increasing activation diameter. That is, there was an apparent change in aerosol composition with size, with particles larger than $\sim 100 \mathrm{~nm}$ containing a larger fraction of more hygroscopic material, similar to what was observed during the year-long study (Levin et al., 2012). We must also note that the $\kappa$ values presented here only represent the aerosol near the activation diameters. Particles larger or smaller than this range could have different chemical composition, and thus different $\kappa$. Furthermore, the size-resolved CCNC measurements provide a single $\kappa$ value for each critical activation diameter. If the aerosol at that size is internally mixed, this $\kappa$ value will be representative of any particle at that size. However, if there are externally mixed aerosol populations at the $d_{\mathrm{c}}$, the calculated $\kappa$ value will represent an average $\kappa$ for particles at that size. Both Su et al. (2010) and Petters et al. (2009a) show that externally mixed aerosol with differing $\kappa$ values will result in a bimodal distribution of activated fraction or distributions that never reach a value of 1 . During BEACHON-RoMBAS we did not observe either of these phenomena, and thus conclude that at a given activation diameter the aerosol was internally mixed or at least contained aerosol with similar hygroscopicity.

\subsection{Aerosol composition}

Levin et al. (2012) suggested that the aerosol measured during the year-long BEACHON study was predominantly organic, based on the low $\kappa$ values, but there were no direct chemical measurements available to corroborate this claim. The similarly low $\kappa$ values determined during BEACHONRoMBAS also suggest a highly organic aerosol. During BEACHON-RoMBAS, submicron aerosol chemical composition was measured with the AMS and TDCIMS. Contour plots of daily averaged organic and inorganic aerosol mass distributions determined from AMS measurements are shown in Fig. 2, and the study-averaged organic mass fraction $\left(X_{\mathrm{org}}\right)$ as a function of particle diameter is shown in Fig. 3. To compare AMS results with those from the CCNC system, we converted vacuum aerodynamic diameter, measured by the AMS, to mobility diameter by dividing by the study averaged aerosol density, using values of 1.4 (Bahreini et al., 2005; Kroll and Seinfeld, 2005; Poulain et al., 2010) and $1.8 \mathrm{~g} \mathrm{~cm}^{-3}$ (Tang, 1996) for the organic and inorganic fractions, respectively. Orange shading in Fig. 3 indicates the range in AMS $X_{\text {org }}$ due to instrument uncertainty (Bahreini et al., 2009). Although the AMS can resolve a number of organic and inorganic species, we have binned the data 


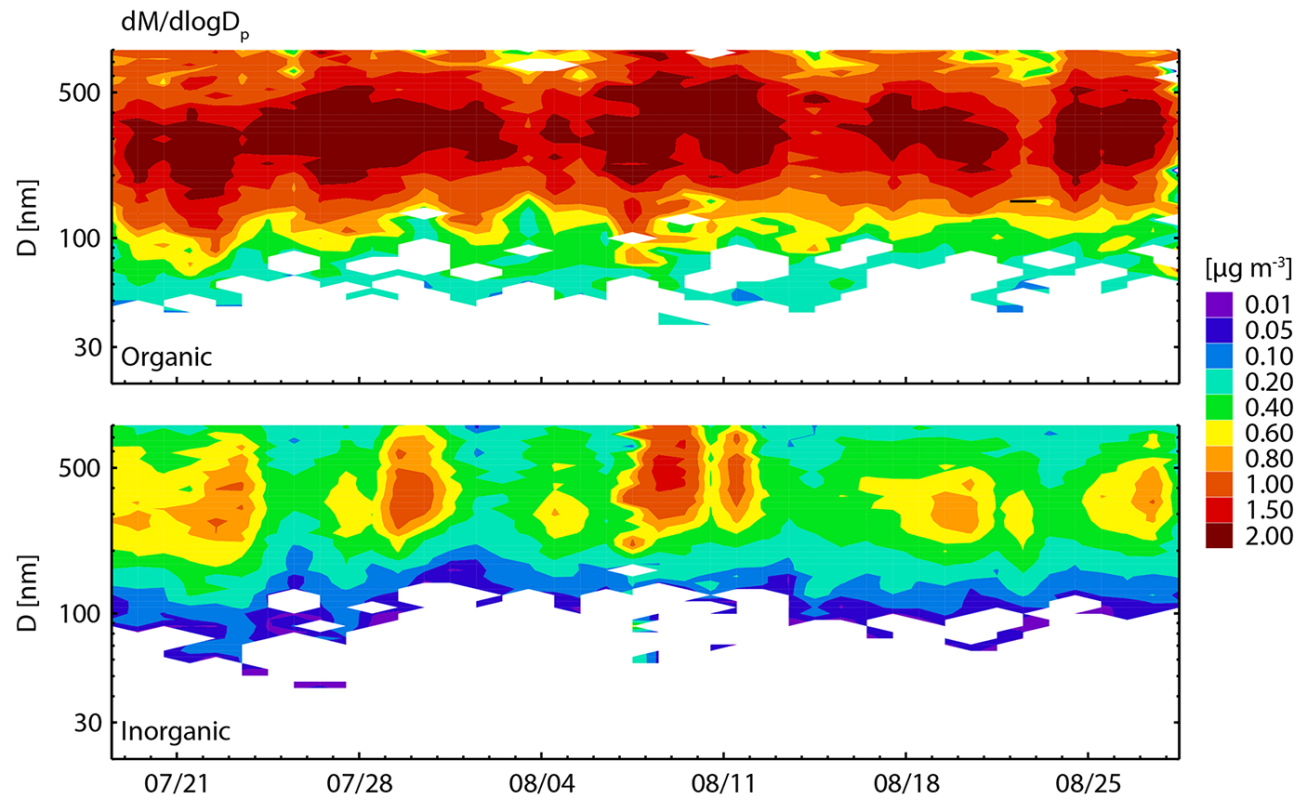

Fig. 2. Organic (top) and inorganic (bottom) mass distributions measured by the AMS during BEACHON-RoMBAS

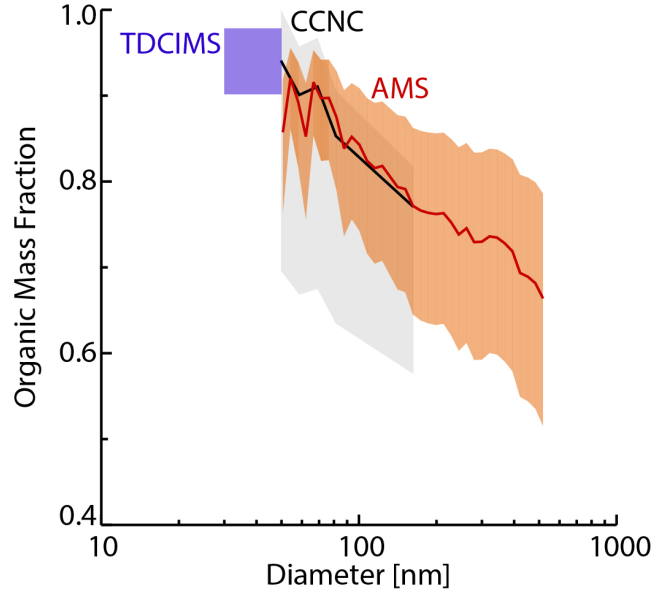

Fig. 3. Aerosol organic mass fraction $\left(X_{\text {org }}\right)$ measured by AMS (red) and TDCIMS (blue) as well as organic mass fraction calculated from size-resolved CCN measurements (black). Gray shading represents the range in $X_{\text {org }}$ derived from CCNC data for values of $\kappa_{\text {org }}=0-0.15$. Orange shading indicates AMS measurement uncertainty. The range in TDCIMS-derived $X_{\text {org }}$ reflects the uncertainty in the molecular weight of the organic aerosol.

into these two components to compare them with the twocomponent composition which can be estimated from sizeresolved CCNC measurements (discussed below). The AMS data indicate that the inorganic mass concentration consisted primarily of ammonium sulfate, calculated as the measured $\mathrm{SO}_{4}^{2-}$ mass multiplied by 1.37 , assuming that all sulfate was in the form of $\left(\mathrm{NH}_{4}\right)_{2} \mathrm{SO}_{4}$. This method was used rather than using the AMS ammonium measurements since the preci- sion of sulfate measurements was much higher than for ammonium in the particle time-of-flight mode. While acidic forms of sulfate could exist in the aerosol, AMS measurements, using the higher precision "mass spec" mode, indicated sufficient $\mathrm{NH}_{4}^{+}$mass to fully neutralize the aerosol during BEACHON-RoMBAS. Nitrate mass was extremely low, often below the detection limit, and, when present, was associated with organic nitrate aerosol (Fry et al., 2013). Other inorganic species were negligible in the AMS measurements during BEACHON-RoMBAS. As expected, the organic fraction was the dominant component of the aerosol throughout the study, with a few periods of increased inorganic mass concentration. Averaged over the whole study (Fig. 3), organics were the main aerosol component at all sizes, with their relative contribution increasing at smaller sizes.

Extending composition measurements to smaller sizes, the TDCIMS provided composition data for particles $30-50 \mathrm{~nm}$ in diameter. These data are also shown in Fig. 3 (blue bar) with the width of the bar representing the range in $X_{\text {org }}$ for a range of assumed organic aerosol molecular weights $\left(100-500 \mathrm{~g} \mathrm{~mol}^{-1}\right)$. These data are consistent with the observed trends from the AMS, showing that these small particles were predominantly organic. Organic compounds appear to play a critical role in the growth of nucleation mode particles to CCN sizes (Dusek et al., 2010). The role of organic compounds in growth of small particles was supported by observations in the year-long BEACHON study, in which aerosol hygroscopicity appeared to be affected by shifts in size distributions typical of new particle formation (NPF) events, with $\kappa$ over most of the measured size range decreasing as the newly formed particles grew to sizes large enough to activate as CCN (Levin et al., 2012). While 


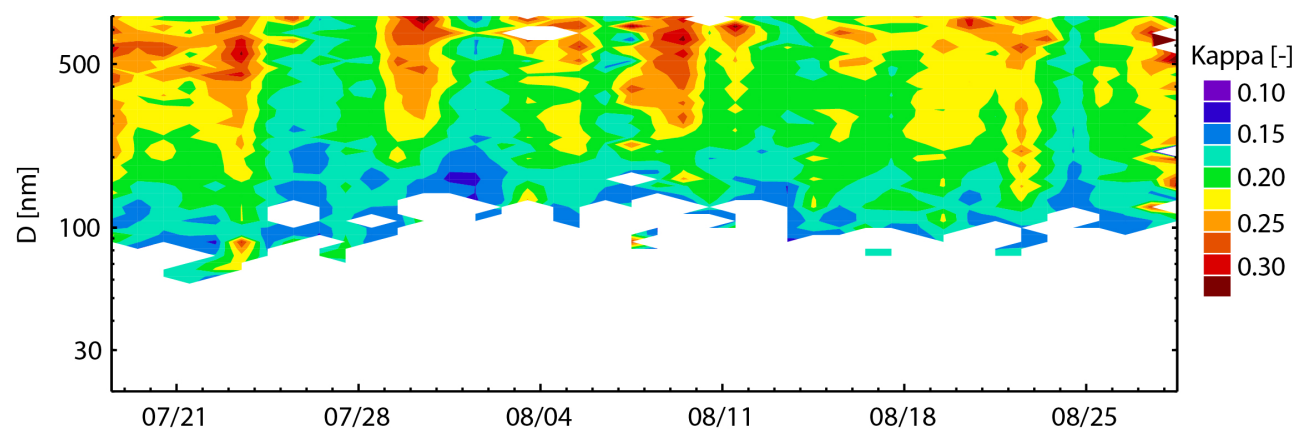

Fig. 4. Daily $\kappa$ distributions calculated from AMS measured aerosol composition.

newly formed, organic particles dominated at small sizes, AMS measurements showed an increasing inorganic fraction at larger aerosol diameters. Given this enhanced inorganic fraction and the lack of local sulfate emissions, it is most likely that the inorganic aerosol was more aged and may have undergone some cloud processing, as cloud droplet residual particles have been shown to have increased sulfate concentrations (Hao et al., 2013). Similarly, enhanced hygroscopicity for particles larger than $\sim 100 \mathrm{~nm}$ was observed by Fors et al. (2011) during long-term measurements at a background site in Sweden. This increased hygroscopicity was also attributed to an enhanced inorganic component due to cloud processing.

\subsection{Kappa composition closure}

To compare the AMS measurements with those from the size-resolved CCNC, we calculated organic volume fractions $\left(\varepsilon_{\text {org }}\right)$ from measured $\kappa$ values by rearranging Eq. 1:

$\varepsilon_{\text {org }}=\frac{\left(\kappa-\kappa_{\text {inorg }}\right)}{\left(\kappa_{\text {org }}-\kappa_{\text {inorg }}\right)}$.

We used a $\kappa_{\text {inorg }}$ value of 0.6 , assuming the inorganic aerosol fraction was predominately ammonium sulfate, and allowed $\kappa_{\text {org }}$ to vary from 0 to 0.15 . We chose 0.15 as the maximum allowed value for $\kappa_{\text {org }}$ as this was the lowest average $\kappa$ value determined during BEACHON-RoMBAS; assuming a higher value of $\kappa_{\text {org }}$ would have led to a physically meaningless, negative inorganic volume fraction, given the twocomponent system. We also assumed that the range in $\kappa_{\text {org }}$ did not change over the course of the study or as a function of size. To convert from volume fractions calculated from $\mathrm{Eq}$ 2 to mass fractions, we multiplied the volume fractions by the assumed densities of 1.4 and $1.8 \mathrm{~g} \mathrm{~cm}^{-3}$ for the organic and inorganic fractions, respectively. Figure 3 shows the studyaveraged organic mass fraction $\left(X_{\mathrm{org}}\right)$ calculated from $\kappa$ as a function of study-averaged critical activation diameter. The gray shaded region shows the range in $X_{\text {org }}$ resulting from the range in assumed $\kappa_{\text {org }}$ values $(0-0.15)$. Regardless of the assumption made about the hygroscopicity of the organic material during the study, Figure 3 clearly shows that the organic fraction dominated aerosol mass at all measured sizes. There was also a decrease in $X_{\text {org }}$ with increasing activation diameter, as expected from the higher average $\kappa$ values at these sizes.

Averaged over the whole study, the best agreement (minimum $\chi^{2}$ ) between $X_{\text {org }}$ determined from $\kappa$ values and AMS measurements was for a $\kappa_{\text {org }}$ value of 0.13 (black line in Fig. 3). In the diameter range where the CCNC and AMS measurements overlap, the agreement in organic mass fraction using this value of $\kappa_{\text {org }}$ is very good, indicating little size dependence in $\kappa_{\text {org }}$ or any of the other assumptions inherent in these calculations. Further, the trend of decreasing $X_{\text {org }}$ with increasing size is very similar for the two measurements.

We also calculated daily averaged $\kappa$ distributions from the AMS organic and inorganic mass measurements $\left(\kappa_{\mathrm{AMS}}\right)$. To do this, we first converted AMS measured mass to volume fractions using the assumed densities mentioned above and then used Eq. (1). and the best fit value of size-independent $\kappa_{\text {org }}, 0.13$, to calculate $\kappa_{\text {AMS }}$. These values are shown in Fig. 4 . We then selected the $\kappa_{\text {AMS }}$ values at the diameters corresponding to the $d_{\mathrm{c}}$ for each CCNC $s$ setting and plotted these in Fig. 1 to compare with $\kappa$ derived from CCNC measurements $\left(\kappa_{\mathrm{CCNC}}\right)$. The error bars for $\kappa_{\mathrm{AMS}}$ in Fig. 1 represent AMS uncertainty.

Overall, there is good agreement between $\kappa_{\mathrm{AMS}}$ and $\kappa_{\mathrm{CCNC}}$. For all but the lowest $s$ setting, the largest discrepancies between $\kappa_{\mathrm{AMS}}$ and $\kappa_{\mathrm{CCNC}}$ occurred when total AMS mass concentration at the $d_{\mathrm{c}}$ was near the detection limit, with better agreement at higher mass concentration. At the lowest $s$, largest $d_{\mathrm{c}}$, there is some difference in $\kappa$ at the beginning of the study, during a period of relatively high AMS mass concentration, but then there is good agreement after this time period. During the early time period (7/18-7/22), AMS measurements indicated an increased inorganic mass concentration, and thus higher $\kappa$, at sizes slightly larger than the largest CCNC $d_{\mathrm{c}}(\sim 150 \mathrm{~nm})$. There was also a sharp gradient in inorganic mass concentrations between 150 and $250 \mathrm{~nm}$. The higher $\kappa_{\mathrm{CCNC}}$ values during this time period could be affected by larger, multiply charged particles appearing in smaller DMA size bins. Although we correct total 

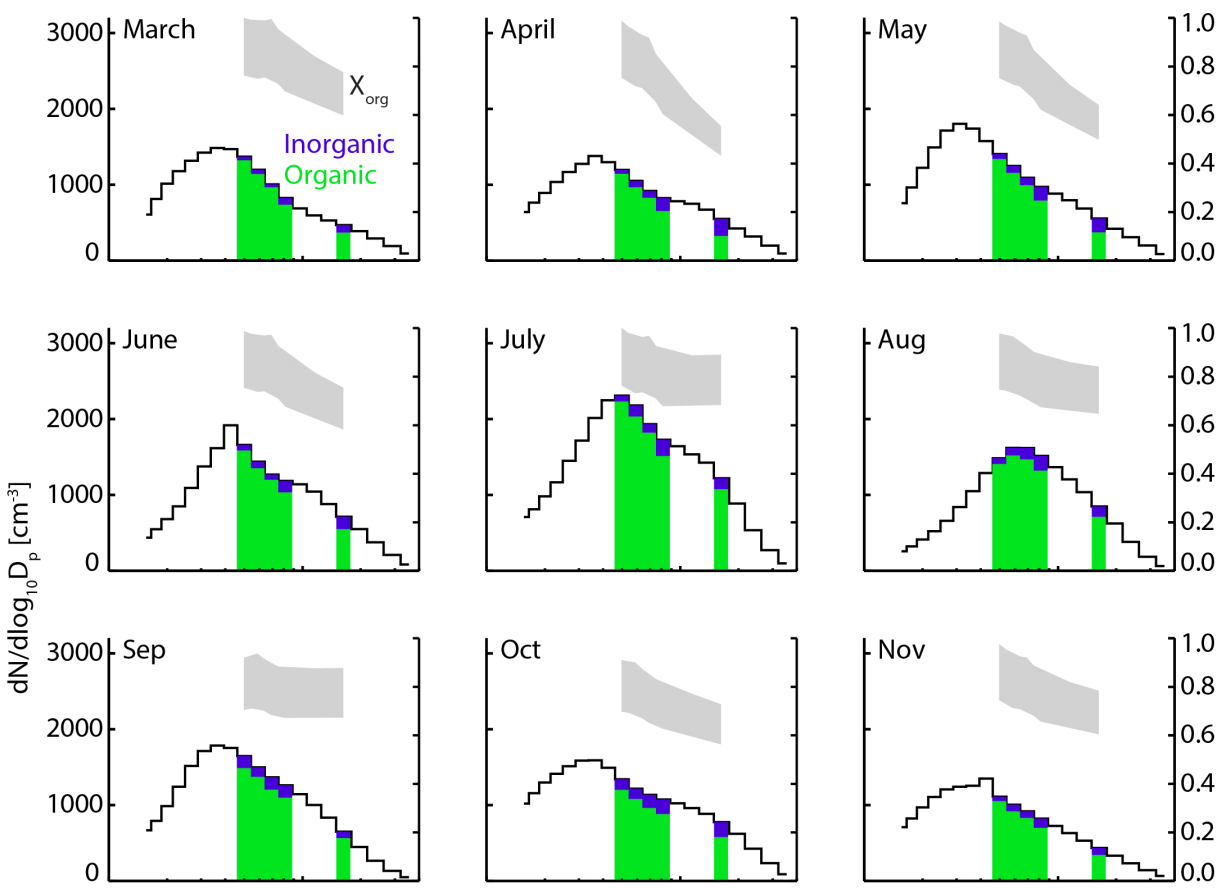

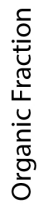
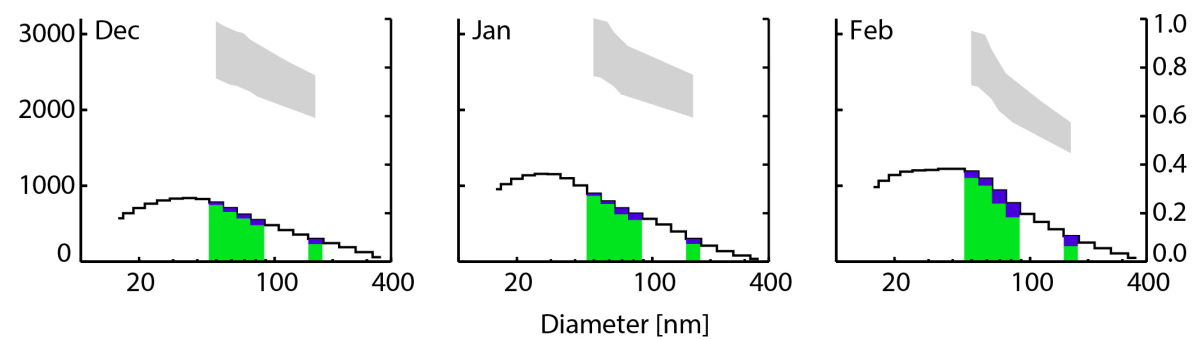

Fig. 5. Monthly averaged aerosol size distributions (black) and two-component chemical composition $($ green $=$ organic, blue $=$ inorganic) calculated from hygroscopicity measurements during the year-long BEACHON study. Gray shading shows the range in organic mass fraction $\left(X_{\text {org }}\right)$ due to uncertainty in $\kappa_{\text {org }}$.

aerosol and CCN number distributions for multiply charged particles (Petters et al., 2009a), size-dependent chemical differences in the aerosol are not accounted for in the inversion and could impact measured $\kappa$ values.

From Fig. 2 it can be seen that the $\kappa_{\text {AMS }}$ values shown in Fig. 1 were calculated at diameters where mass loadings were very low, especially at the smaller $d_{\mathrm{c}}$ values. At smaller sizes, this resulted in more variable $\kappa_{\mathrm{AMS}}$ values, and in many cases we were unable to calculate $\kappa_{\text {AMS }}$ because mass was below the AMS detection limit. At larger diameters, above the measurable range for the CCNC system, the AMS values are likely more certain, due to the higher mass concentrations at these sizes. By contrast, the CCNC is a number-based measurement, and is thus most reliable at diameters with the highest number concentrations, so that comparing results from these two systems is challenging. Nevertheless, the general agreement between $X_{\text {org }}$ and $\kappa$ determined from these two measurement systems in this case supports the use of the AMS data to calculate hygroscopicity, and the size-resolved
CCNC data to calculate two-component aerosol composition. Furthermore, while the AMS can only detect nonrefractory particles, it appears to capture the important species for determining aerosol hygroscopicity in this size range at this site.

\subsection{Seasonal aerosol composition}

Based on the generally good agreement between aerosol composition measured by the AMS and calculated from CCNC data during BEACHON-RoMBAS, we used the yearlong CCNC data reported by Levin et al. (2012), and the same methods discussed above, to calculate monthly averaged, two-component aerosol composition distributions for a full year. These distributions are shown in Fig. 5 with the green and blue bars showing the organic and inorganic components, respectively. As before, the gray shaded region shows the range in calculated organic mass fraction for assumed $\kappa_{\text {org }}$ values. However, the range in assumed $\kappa_{\text {org }}$ had 
to be limited to $0<\kappa_{\text {org }}<0.12$ for the year-long data set in order to avoid a negative calculated $X_{\text {inorg }}$ value during some months. Since a best-fit value of $\kappa_{\text {org }}=0.13$ was observed during BEACHON-RoMBAS, this could indicate some seasonal changes in the composition of the organic aerosol at this site or the influence of other low- $\kappa$ aerosol components, such as dust or black carbon.

We observed a similar trend throughout the year-long study period as that seen during the intensive BEACHONRoMBAS campaign, with aerosol organic fraction decreasing with increasing diameter. There was, however, some seasonality in this pattern. Aerosol composition was least sizedependent during the late summer and early fall, and then the variability with particle diameter steadily increased throughout the winter and into the spring. The largest change in organic fraction with size was observed during April, when $X_{\text {org }}$ decreased to $\sim 0.5$ at the largest measured size. The seasonal change in $X_{\text {org }}$ for particles at the largest measured size is consistent with the seasonal variability of volatile organic compound (VOC) emissions (Saarikoski et al., 2008), which are precursors for SOA production. Likewise, while NPF events occur year round, they were most common in the summer months at Manitou Experimental Forest (Levin et al., 2012), and could be a contributing factor to the increased $X_{\text {org }}$ values during this time period. Less seasonality was observed in the inferred composition of the smallest measured particles, which remained almost entirely organic throughout the year-long study period.

\section{Summary and conclusions}

Atmospheric particles that act as $\mathrm{CCN}$ are important in controlling cloud and precipitation formation and lifetime, and can have considerable effects on local to global scales. Highquality measurements of CCN concentration and aerosol hygroscopicity are needed to constrain modeled cloud and precipitation processes, and explore their subsequent impacts on water cycles and radiative transfer. In this paper we present aerosol composition and hygroscopicity data from a forested site in the eastern Rocky Mountains of Colorado made as part of BEACHON-RoMBAS. We used size-resolved CCN measurements to determine aerosol hygroscopicity and measured aerosol chemical composition with an AMS and TDCIMS, and found consistency between measured hygroscopicity and aerosol composition from the AMS and TDCIMS. Likewise, we show that $\mathrm{CCN}$-derived $\kappa$ values can be used to calculate aerosol composition, assuming conditions are met for a simple two-component system composed of organic aerosol of size-independent $\kappa$ and an inorganic aerosol dominated by sulfate. Over the intensive summer study, the best agreement between measured and calculated aerosol composition was achieved for an assumed value of $\kappa_{\text {org }}=0.13$.

Aerosol chemical composition and hygroscopicity measurements showed that the aerosol measured at the BEA-
CHON site was predominantly organic, and thus had low $\kappa$ values. Averaged over the entire year-long BEACHON study, and all $s$ settings, $\kappa$ had an average value of $0.16 \pm 0.08$, similar to values determined in biogenic organic dominated locations such as a tropical forest in the Amazon during the wet season (Gunthe et al., 2009; Pöschl et al., 2010) and a boreal forest in Finland (Sihto et al., 2011), and lower than the commonly assumed value of $\kappa_{\text {continental }}=0.3$. The relatively low $\kappa$ values measured at these locations dominated by biogenic emissions suggest a predominance and potential importance of organic species, which generally have low hygroscopicity (Prenni et al., 2007; Petters et al., 2009b; King et al., 2010). It is known that highly biologically active areas such as boreal and tropical forests will have large contributions from organic aerosol leading to low $\kappa$ values. However, results from this study indicate that the aerosol in this Colorado, semi-arid, high altitude location is also dominated by organic species.

While organic species were dominant at all sizes, there were some changes in aerosol composition with size, with the organic fraction typically decreasing at larger diameters. The increased inorganic fraction of larger particles likely indicates that these particles were more aged and had likely undergone some cloud processing. The trend of decreasing organic fraction with larger diameters was observed year round, however, there was some seasonality observed during the year-long BEACHON study. During the winter months, there was a sharper decrease in calculated organic mass fraction with size, although even at the largest diameter $(\sim$ $150 \mathrm{~nm}$ ) the aerosol was still predominantly organic. During the summer months, there was less size dependence in composition. We postulate that the increased organic fraction at larger diameters during the summer is due to increased biological activity during this time period, resulting in increased emissions of biogenic volatile organic compounds, which are precursors of organic aerosol.

Acknowledgements. This work is funded by NSF (ATM-0919042). The National Center for Atmospheric Research (NCAR) is sponsored by the US National Science Foundation. We thank M. D. Petters for the use of his Labview and IDL codes to operate the instruments and process data. The CU group was partially supported by NOAA NA13OAR4310063 and NSF AGS-1243354.

Edited by: R. Holzinger

\section{References}

Albrecht, B. A.: Aerosols, cloud microphysics, and fractional cloudiness, Science, 245, 1227-1230, 1989.

Andreae, M. O., and Rosenfeld, D.: Aerosol-cloudprecipitation interactions. Part 1 . The nature and sources of cloud-active aerosols, Earth-Sci. Rev., 89, 13-41, doi:10.1016/j.earscirev.2008.03.001, 2008. 
Asa-Awuku, A., Nenes, A., Gao, S., Flagan, R. C., and Seinfeld, J. H.: Water-soluble SOA from Alkene ozonolysis: composition and droplet activation kinetics inferences from analysis of CCN activity, Atmos. Chem. Phys., 10, 1585-1597, doi:10.5194/acp10-1585-2010, 2010.

Bahreini, R., Keywood, M. D., Ng, N. L., Varutbangkul, V., Gao, S., Flagan, R. C., Seinfeld, J. H., Worsnop, D. R., and Jimenez, J. L.: Measurements of secondary organic aerosol from oxidation of cycloalkenes, terpenes, and m-xylene using an Aerodyne aerosol mass spectrometer, Environ. Sci. Technol., 39, 5674-5688, 2005.

Bahreini, R., Ervens, B., Middlebrook, A. M., Warneke, C., de Gouw, J. A., DeCarlo, P. F., Jimenez, J. L., Brock, C. A., Neuman, J. A., Ryerson, T. B., Stark, H., Atlas, E., Brioude, J., Fried, A., Holloway, J. S., Peischl, J., Richter, D., Walega, J., Weibring, P., Wollny, A. G., and Fehsenfeld, F. C.: Organic aerosol formation in urban and industrial plumes near Houston and Dallas, Texas, J. Geophys. Res.-Atmos., 114, D00F16, doi:10.1029/2008jd011493, 2009.

Canagaratna, M. R., Jayne, J. T., Jimenez, J. L., Allan, J. D., Alfarra, M. R., Zhang, Q., Onasch, T. B., Drewnick, F., Coe, H., Middlebrook, A., Delia, A., Williams, L. R., Trimborn, A. M., Northway, M. J., DeCarlo, P. F., Kolb, C. E., Davidovits, P., and Worsnop, D. R.: Chemical and microphysical characterization of ambient aerosols with the aerodyne aerosol mass spectrometer, Mass Spectrom. Rev., 26, 185-222, doi:10.1002/mas.20115, 2007.

Cerully, K. M., Raatikainen, T., Lance, S., Tkacik, D., Tiitta, P., Petäjä, T., Ehn, M., Kulmala, M., Worsnop, D. R., Laaksonen, A., Smith, J. N., and Nenes, A.: Aerosol hygroscopicity and CCN activation kinetics in a boreal forest environment during the 2007 EUCAARI campaign, Atmos. Chem. Phys., 11, 12369-12386, doi:10.5194/acp-11-12369-2011, 2011.

Chang, R. Y. W., Slowik, J. G., Shantz, N. C., Vlasenko, A., Liggio, J., Sjostedt, S. J., Leaitch, W. R., and Abbatt, J. P. D.: The hygroscopicity parameter (kappa) of ambient organic aerosol at a field site subject to biogenic and anthropogenic influences: relationship to degree of aerosol oxidation, Atmos. Chem. Phys., 10, 5047-5064, doi:10.5194/acp-10-5047-2010, 2010.

Clegg, S. L., Brimblecombe, P., and Wexler, A. S.: Thermodynamic model of the system $\mathrm{H}+-\mathrm{NH}_{4}^{+}-\mathrm{SO}_{4}^{2-}-\mathrm{NO}_{3}^{-}-\mathrm{H}_{2} \mathrm{O}$ at tropospheric temperatures, J. Phys. Chem. A, 102, 2137-2154, 1998.

DeCarlo, P. F., Kimmel, J. R., Trimborn, A., Northway, M. J., Jayne, J. T., Aiken, A. C., Gonin, M., Fuhrer, K., Horvath, T., Docherty, K. S., Worsnop, D. R., and Jimenez, J. L.: Field-deployable, high-resolution, time-of-flight aerosol mass spectrometer, Anal. Chem., 78, 8281-8289, doi:10.1021/ac061249n, 2006.

Drewnick, F., Hings, S. S., DeCarlo, P., Jayne, J. T., Gonin, M., Fuhrer, K., Weimer, S., Jimenez, J. L., Demerjian, K. L., Borrmann, S., and Worsnop, D. R.: A new time-of-flight aerosol mass spectrometer (TOF-AMS) - Instrument description and first field deployment, Aerosol Sci. Technol., 39, 637-658, doi:10.1080/02786820500182040, 2005.

Dusek, U., Frank, G. P., Curtius, J., Drewnick, F., Schneider, J., Kurten, A., Rose, D., Andreae, M. O., Borrmann, S., and Pöschl, U.: Enhanced organic mass fraction and decreased hygroscopicity of cloud condensation nuclei (CCN) during new particle formation events, Geophys. Res. Lett., 37, L03804, doi:10.1029/2009g1040930, 2010.
Engelhart, G. J., Asa-Awuku, A., Nenes, A., and Pandis, S. N.: CCN activity and droplet growth kinetics of fresh and aged monoterpene secondary organic aerosol, Atmos. Chem. Phys., 8, 39373949, doi:10.5194/acp-8-3937-2008, 2008.

Engelhart, G. J., Moore, R. H., Nenes, A., and Pandis, S. N.: Cloud condensation nuclei activity of isoprene secondary organic aerosol, J. Geophys. Res.-Atmos., 116, D02207 10.1029/2010jd014706, 2011.

Fors, E. O., Swietlicki, E., Svenningsson, B., Kristensson, A., Frank, G. P., and Sporre, M.: Hygroscopic properties of the ambient aerosol in southern Sweden - a two year study, Atmos. Chem. Phys., 11, 8343-8361, doi:10.5194/acp-11-8343-2011, 2011.

Frosch, M., Bilde, M., DeCarlo, P. F., Juranyi, Z., Tritscher, T., Dommen, J., Donahue, N. M., Gysel, M., Weingartner, E., and Baltensperger, U.: Relating cloud condensation nuclei activity and oxidation level of alpha-pinene secondary organic aerosols, J. Geophys. Res.-Atmos., 116, D22212, doi:10.1029/2011jd016401, 2011.

Fry, J. L., Draper, D. C., Zarzana, K. J., Campuzano-Jost, P., Day, D. A., Jimenez, J. L., Brown, S. S., Cohen, R. C., Kaser, L., Hansel, A., Cappellin, L., Karl, T., Hodzic Roux, A., Turnipseed, A., Cantrell, C., Lefer, B. L., and Grossberg, N.: Observations of gas- and aerosol-phase organic nitrates at BEACHON-RoMBAS 2011, Atmos. Chem. Phys., 13, 8585-8605, doi:10.5194/acp-138585-2013, 2013.

Gunthe, S. S., King, S. M., Rose, D., Chen, Q., Roldin, P., Farmer, D. K., Jimenez, J. L., Artaxo, P., Andreae, M. O., Martin, S. T., and Pöschl, U.: Cloud condensation nuclei in pristine tropical rainforest air of Amazonia: size-resolved measurements and modeling of atmospheric aerosol composition and CCN activity, Atmos. Chem. Phys., 9, 7551-7575, doi:10.5194/acp-9-75512009, 2009.

Hao, L. Q., Romakkaniemi, S., Kortelainen, A., Jaatinen, A., Portin, H., Miettinen, P., Komppula, M., Leskinen, A., Virtanen, A., Smith, J. N., Sueper, D., Worsnop, D. R., Lehtinen, K. E. J., and Laaksonen, A.: Aerosol Chemical Composition in Cloud Events by High Resolution Time-of-Flight Aerosol Mass Spectrometry, Environ. Sci. Technol., 47, 2645-2653, doi:10.1021/es302889w, 2013.

Juranyi, Z., Gysel, M., Weingartner, E., Bukowiecki, N., Kammermann, L., and Baltensperger, U.: A 17 month climatology of the cloud condensation nuclei number concentration at the high alpine site Jungfraujoch, J. Geophys. Res.-Atmos., 116, doi:10.1029/2010jd015199, 2011.

Kanakidou, M., Seinfeld, J. H., Pandis, S. N., Barnes, I., Dentener, F. J., Facchini, M. C., Van Dingenen, R., Ervens, B., Nenes, A., Nielsen, C. J., Swietlicki, E., Putaud, J. P., Balkanski, Y., Fuzzi, S., Horth, J., Moortgat, G. K., Winterhalter, R., Myhre, C. E. L., Tsigaridis, K., Vignati, E., Stephanou, E. G., and Wilson, J.: Organic aerosol and global climate modelling: a review, Atmos. Chem. Phys., 5, 1053-1123, doi:10.5194/acp-5-1053-2005, 2005.

Khain, A., Rosenfeld, D., and Pokrovsky, A.: Aerosol impact on the dynamics and microphysics of deep convective clouds, Q. J. Roy. Meteorol. Soc., 131, 2639-2663, doi:10.1256/qj.04.62, 2005.

Khain, A., and Lynn, B.: Simulation of a supercell storm in clean and dirty atmosphere using weather research and forecast model with spectral bin microphysics, J. Geophys. Res.-Atmos., 114, D19209, doi:10.1029/2009jd011827, 2009. 
Kim, S., Karl, T., Guenther, A., Tyndall, G., Orlando, J., Harley, P., Rasmussen, R., and Apel, E.: Emissions and ambient distributions of Biogenic Volatile Organic Compounds (BVOC) in a ponderosa pine ecosystem: interpretation of PTR-MS mass spectra, Atmos. Chem. Phys., 10, 1759-1771, doi:10.5194/acp-101759-2010, 2010.

King, S. M., Rosenoern, T., Shilling, J. E., Chen, Q., Wang, Z., Biskos, G., McKinney, K. A., Pöschl, U., and Martin, S. T.: Cloud droplet activation of mixed organic-sulfate particles produced by the photooxidation of isoprene, Atmos. Chem. Phys., 10, 3953-3964, doi:10.5194/acp-10-3953-2010, 2010.

Koehler, K. A., DeMott, P. J., Kreidenweis, S. M., Popovicheva, O. B., Petters, M. D., Carrico, C. M., Kireeva, E. D., Khokhlova, T. D., and Shonija, N. K.: Cloud condensation nuclei and ice nucleation activity of hydrophobic and hydrophilic soot particles, Phys. Chem. Chem. Phys., 11, 79067920, doi:10.1039/b905334b, 2009.

Kroll, J. H. and Seinfeld, J. H.: Representation of secondary organic aerosol laboratory chamber data for the interpretation of mechanisms of particle growth, Environ. Sci. Technol., 39, 4159-4165, doi:10.1021/es048292h, 2005.

Kulmala, M., Suni, T., Lehtinen, K. E. J., Dal Maso, M., Boy, M., Reissell, A., Rannik, U., Aalto, P., Keronen, P., Hakola, H., Back, J. B., Hoffmann, T., Vesala, T., and Hari, P.: A new feedback mechanism linking forests, aerosols, and climate, Atmos. Chem. Phys., 4, 557-562, doi:10.5194/acp-4-557-2004, 2004a.

Kulmala, M., Vehkamaki, H., Petaja, T., Dal Maso, M., Lauri, A., Kerminen, V. M., Birmili, W., and McMurry, P. H.: Formation and growth rates of ultrafine atmospheric particles: a review of observations, J. Aerosol Sci., 35, 143-176, doi:10.1016/j.jaerosci.2003.10.003, 2004b.

Lerach, D. G. and Cotton, W. R.: Comparing Aerosol and LowLevel Moisture Influences on Supercell Tornadogenesis: ThreeDimensional Idealized Simulations, J. Atmos. Sci., 69, 969-987, doi:10.1175/jas-d-11-043.1, 2012.

Levin, E. J. T., Kreidenweis, S. M., McMeeking, G. R., Carrico, C. M., Collett, J. L., and Malm, W. C.: Aerosol physical, chemical and optical properties during the Rocky Mountain Airborne Nitrogen and Sulfur study, Atmos. Environ., 43, 1932-1939, doi:10.1016/j.atmosenv.2008.12.042, 2009.

Levin, E. J. T., Prenni, A. J., Petters, M. D., Kreidenweis, S. M., Sullivan, R. C., Atwood, S. A., Ortega, J., DeMott, P. J., and Smith, J. N.: An annual cycle of size-resolved aerosol hygroscopicity at a forested site in Colorado, J. Geophys. Res.-Atmos., 117, D06201, doi:10.1029/2011jd016854, 2012.

Malm, W. C., McMeeking, G. R., Kreidenweis, S. M., Levin, E., Carrico, C. M., Day, D. E., Collett, J. L., Lee, T., Sullivan, A. P., and Raja, S.: Using High Time Resolution Aerosol and Number Size Distribution Measurements to Estimate Atmospheric Extinction, J. Air Waste Manage. Assoc., 59, 1049-1060, doi:10.3155/1047-3289.59.9.1049, 2009.

Massoli, P., Lambe, A. T., Ahern, A. T., Williams, L. R., Ehn, M., Mikkila, J., Canagaratna, M. R., Brune, W. H., Onasch, T. B., Jayne, J. T., Petaja, T., Kulmala, M., Laaksonen, A., Kolb, C. E., Davidovits, P., and Worsnop, D. R.: Relationship between aerosol oxidation level and hygroscopic properties of laboratory generated secondary organic aerosol (SOA) particles, Geophys. Res. Lett., 37, 5, L24801, doi:10.1029/2010g1045258, 2010.
Ortega, J., Turnipseed, A., Guenther, A. B., Karl, T. G., Day, D. A., Gochis, D., Huffman, J. A., Prenni, A. J., Levin, E. J. T., Kreidenweis, S. M., DeMott, P. J., Tobo, Y., Patton, E. G., Hodzic, A., Cui, Y., Harley, P. C., Hornbrook, R. H., Apel, E. C., Monson, R. K., Eller, A. S. D., Greenberg, J. P., Barth, M., CampuzanoJost, P., Palm, B. B., Jimenez, J. L., Aiken, A. C., Dubey, M. K., Geron, C., Offenberg, J., Ryan, M. G., Fornwalt, P. J., Pryor, S. C., Keutsch, F. N., DiGangi, J. P., Chan, A. W. H., Goldstein, A. H., Wolfe, G. M., Kim, S., Kaser, L., Schnitzhofer, R., Hansel, A., Cantrell, C. A., Mauldin III, R. L., and Smith, J. N.: Overview of the Manitou Experimental Forest Observatory: site description and selected science results from 2008-2013, Atmos. Chem. Phys. Discuss., 14, 1647-1709, doi:10.5194/acpd14-1647-2014, 2014.

Paramonov, M., Aalto, P. P., Asmi, A., Prisle, N., Kerminen, V.M., Kulmala, M., and Petäjä, T.: The analysis of size-segregated cloud condensation nuclei counter (CCNC) data and its implications for cloud droplet activation, Atmos. Chem. Phys., 13, 10285-10301, doi:10.5194/acp-13-10285-2013, 2013.

Park, R. J., Jacob, D. J., and Logan, J. A.: Fire and biofuel contributions to annual mean aerosol mass concentrations in the United States, Atmos. Environ., 41, 7389-7400, 2007.

Petters, M. D. and Kreidenweis, S. M.: A single parameter representation of hygroscopic growth and cloud condensation nucleus activity, Atmos. Chem. Phys., 7, 1961-1971, doi:10.5194/acp-71961-2007, 2007.

Petters, M. D., Carrico, C. M., Kreidenweis, S. M., Prenni, A. J., DeMott, P. J., Collett, J. L., and Moosmuller, H.: Cloud condensation nucleation activity of biomass burning aerosol, J. Geophys. Res.-Atmos., 114, D22205, doi:10.1029/2009jd012353, 2009a.

Petters, M. D., Kreidenweis, S. M., Prenni, A. J., Sullivan, R. C., Carrico, C. M., Koehler, K. A., and Ziemann, P. J.: Role of molecular size in cloud droplet activation, Geophys. Res. Lett., 36, L22801, doi:10.1029/2009g1040131, 2009b.

Pierce, J. R., Leaitch, W. R., Liggio, J., Westervelt, D. M., Wainwright, C. D., Abbatt, J. P. D., Ahlm, L., Al-Basheer, W., Cziczo, D. J., Hayden, K. L., Lee, A. K. Y., Li, S. M., Russell, L. M., Sjostedt, S. J., Strawbridge, K. B., Travis, M., Vlasenko, A., Wentzell, J. J. B., Wiebe, H. A., Wong, J. P. S., and Macdonald, A. M.: Nucleation and condensational growth to $\mathrm{CCN}$ sizes during a sustained pristine biogenic SOA event in a forested mountain valley, Atmos. Chem. Phys., 12, 3147-3163, doi:10.5194/acp-12-3147-2012, 2012.

Pöschl, U., Rose, D., and Andreae, M. O.: Part 2: Particle Hygroscopicity and Cloud Condensation Nucleus Activity, Clouds in the Perturbed Climate System: Their Relationship to Energy Balance, Atmospheric Dynamics, and Precipitation, MIT Press, Cambridge, MA, 58-72, 2009.

Poulain, L., Wu, Z., Petters, M. D., Wex, H., Hallbauer, E., Wehner, B., Massling, A., Kreidenweis, S. M., and Stratmann, F.: Towards closing the gap between hygroscopic growth and $\mathrm{CCN}$ activation for secondary organic aerosols - Part 3: Influence of the chemical composition on the hygroscopic properties and volatile fractions of aerosols, Atmos. Chem. Phys., 10, 37753785, doi:10.5194/acp-10-3775-2010, 2010.

Prenni, A. J., Petters, M. D., Kreidenweis, S. M., DeMott, P. J., and Ziemann, P. J.: Cloud droplet activation of sec- 
ondary organic aerosol, J. Geophys. Res.-Atmos., 112, D10223, doi:10.1029/2006jd007963, 2007.

Pringle, K. J., Tost, H., Pozzer, A., Pöschl, U., and Lelieveld, J.: Global distribution of the effective aerosol hygroscopicity parameter for CCN activation, Atmos. Chem. Phys., 10, 52415255, doi:10.5194/acp-10-5241-2010, 2010.

Pöschl, U., Martin, S. T., Sinha, B., Chen, Q., Gunthe, S. S., Huffman, J. A., Borrmann, S., Farmer, D. K., Garland, R. M., Helas, G., Jimenez, J. L., King, S. M., Manzi, A., Mikhailov, E., Pauliquevis, T., Petters, M. D., Prenni, A. J., Roldin, P., Rose, D., Schneider, J., Su, H., Zorn, S. R., Artaxo, P., and Andreae, M. O.: Rainforest Aerosols as Biogenic Nuclei of Clouds and Precipitation in the Amazon, Science, 329, 15131516, doi:10.1126/science.1191056, 2010.

Robinson, N. H., Hamilton, J. F., Allan, J. D., Langford, B., Oram, D. E., Chen, Q., Docherty, K., Farmer, D. K., Jimenez, J. L., Ward, M. W., Hewitt, C. N., Barley, M. H., Jenkin, M. E., Rickard, A. R., Martin, S. T., McFiggans, G., and Coe, H.: Evidence for a significant proportion of Secondary Organic Aerosol from isoprene above a maritime tropical forest, Atmos. Chem. Phys., 11, 1039-1050, doi:10.5194/acp-11-1039-2011, 2011.

Rosenfeld, D., Lohmann, U., Raga, G. B., O’Dowd, C. D., Kulmala, M., Fuzzi, S., Reissell, A., and Andreae, M. O.: Flood or drought: How do aerosols affect precipitation?, Science, 321, 1309-1313, doi:10.1126/science.1160606, 2008.

Saarikoski, S., Timonen, H., Saarnio, K., Aurela, M., Järvi, L., Keronen, P., Kerminen, V.-M., and Hillamo, R.: Sources of organic carbon in fine particulate matter in northern European urban air, Atmos. Chem. Phys., 8, 6281-6295, doi:10.5194/acp-86281-2008, 2008.

Sihto, S. L., Mikkila, J., Vanhanen, J., Ehn, M., Liao, L., Lehtipalo, K., Aalto, P. P., Duplissy, J., Petaja, T., Kerminen, V. M., Boy, M., and Kulmala, M.: Seasonal variation of CCN concentrations and aerosol activation properties in boreal forest, Atmos. Chem. Phys., 11, 13269-13285, doi:10.5194/acp-11-13269-2011, 2011.

Smith, J. N., Moore, K. F., McMurry, P. H., and Eisele, F. L.: Atmospheric measurements of sub-20 nm diameter particle chemical composition by thermal desorption chemical ionization mass spectrometry, Aerosol Science and Technology, 38, 100-110, doi:10.1080/02786820490249036, 2004.

Storer, R. L., van den Heever, S. C., and Stephens, G. L.: Modeling Aerosol Impacts on Convective Storms in Different Environments, J. Atmos. Sci., 67, 3904-3915, doi:10.1175/2010jas3363.1, 2010.

Su, H., Rose, D., Cheng, Y. F., Gunthe, S. S., Massling, A., Stock, M., Wiedensohler, A., Andreae, M. O., and Pöschl, U.: Hygroscopicity distribution concept for measurement data analysis and modeling of aerosol particle mixing state with regard to hygroscopic growth and CCN activation, Atmos. Chem. Phys., 10, 7489-7503, doi:10.5194/acp-10-7489-2010, 2010.
Suda, S. R., Petters, M. D., Matsunaga, A., Sullivan, R. C., Ziemann, P. J., and Kreidenweis, S. M.: Hygroscopicity frequency distributions of secondary organic aerosols, J. Geophys. Res.Atmos., 117, D04207, doi:10.1029/2011jd016823, 2012.

Tang, I. N.: Chemical and size effects of hygroscopic aerosols on light scattering coefficients, J. Geophys. Res.-Atmos., 101, 19245-19250, 1996.

Twomey, S.: Pollution and Planetary Albedo, Atmos. Environ., 8, 1251-1256, 1974.

van den Heever, S. C., Carrio, G. G., Cotton, W. R., DeMott, P. J., and Prenni, A. J.: Impacts of nucleating aerosol on Florida storms. Part I: Mesoscale simulations, J. Atmos. Sci., 63, 17521775, doi:10.1175/jas3713.1, 2006.

van den Heever, S. C., and Cotton, W. R.: Urban aerosol impacts on downwind convective storms, Journal of Appl. Meteorol. Climatol., 46, 828-850, doi:10.1175/jam2492.1, 2007.

van den Heever, S. C., Stephens, G. L., and Wood, N. B.: Aerosol Indirect Effects on Tropical Convection Characteristics under Conditions of Radiative-Convective Equilibrium, J. Atmos. Sci., 68, 699-718, doi:10.1175/2010jas3603.1, 2011.

Voisin, D., Smith, J. N., Sakurai, H., McMurry, P. H., and Eisele, F. L.: Thermal desorption chemical ionization mass spectrometer for ultrafine particle chemical composition, Aerosol Sci.Technol., 37, 471-475, doi:10.1080/02786820390125232, 2003.

Wex, H., Petters, M. D., Carrico, C. M., Hallbauer, E., Massling, A., McMeeking, G. R., Poulain, L., Wu, Z., Kreidenweis, S. M., and Stratmann, F.: Towards closing the gap between hygroscopic growth and activation for secondary organic aerosol: Part 1 - Evidence from measurements, Atmos. Chem. Phys., 9, 3987-3997, doi:10.5194/acp-9-3987-2009, 2009.

Yamashita, K., Murakami, M., Hashimoto, A., and Tajiri, T.: CCN Ability of Asian Mineral Dust Particles and Their Effects on Cloud Droplet Formation, J. Meteorol. Soc. Jpn., 89, 581-587, doi:10.2151/jmsj.2011-512, 2011.

Zhang, Q., Stanier, C. O., Canagaratna, M. R., Jayne, J. T., Worsnop, D. R., Pandis, S. N., and Jimenez, J. L.: Insights into the chemistry of new particle formation and growth events in Pittsburgh based on aerosol mass spectrometry, Environ. Sci. Technol., 38, 4797-4809, doi:10.1021/es035417u, 2004. 